\title{
Epidemiological analysis of hospitalisations due to recurrent stroke in the Silesian Province, Poland, between 2009 and 2015
}

\author{
Beata Łabuz-Roszak ${ }^{1,2}$, Michał Skrzypek ${ }^{3}$, Anna Starostka-Tatar ${ }^{4}$, Anetta Lasek-Bal ${ }^{5}$, Mariusz Gąsior ${ }^{6}$, \\ Marek Gierlotka ${ }^{7}$
}

${ }^{1}$ Department of Basic Medical Sciences, Faculty of Public Health, Medical University of Silesia, Katowice, Poland

${ }^{2}$ Department of Neurology and Stroke Unit, WSS im. Św. Jadwigi, Opole, Poland

${ }^{3}$ Department of Biostatistics, Faculty of Public Health, Medical University of Silesia, Katowice, Poland

${ }^{4}$ Department of Neurology, Independent Public Clinical Hospital No.1 in Zabrze, Medical University of Silesia, Katowice, Poland

${ }^{5}$ Department of Neurology, School of Health Sciences, Medical University of Silesia, Medical Centre of Upper Silesia, Katowice, Poland ${ }^{6} 3$ rd Department of Cardiology, School of Medicine with the Division of Dentistry in Zabrze, Medical University of Silesia, Katowice,

Silesian Centre for Heart Disease in Zabrze, Poland

${ }^{7}$ Department of Cardiology, Institute of Medicine, University of Opole, Opole, Poland

\begin{abstract}
Background and aim. There is a lack of recent epidemiological studies on recurrent stroke (RS) in Poland. The aim of this study was to analyse all hospitalisations related to RS in Silesia - an industrial region covering $12 \%$ of the Polish population. Material and methods. We carried out statistical analysis of data contained in stroke questionnaires transferred to the Polish National Health Fund by hospitals in Silesia, Poland, between 2009 and 2015.

Results. In the analysed period, the number of RS hospitalisations in Silesia was 18,063 (22.2\% of all acute strokes). The percentage of RS significantly decreased during the period under consideration $(p<0.001)$. The same observation concerned recurrent ischaemic stroke (RIS), but not recurrent haemorrhagic stroke (RHS). The median hospitalisation time was 14 days for RHS, and 11 days for RIS. Large-artery atherosclerosis and cardioembolisms were significantly more often recognised in RIS than in first-ever ischaemic stroke (FIS) (consecutively, 38.2\% vs 36.0\%, and $21 \%$ vs $18.1 \%$; $p<0.001$ ). The in-hospital mortality rate was significantly higher for RS than for first-ever stroke ( $18.4 \%$ vs $17.2 \% ; p<0.001)$. The same observation was done for RIS vs FIS $(16.2 \%$ vs $13.9 \% ; p<0.001)$, and for RHS vs FHS ( $39.8 \%$ vs $36 \% ; p=0.004)$. The rtPA therapy was applied to $5.3 \%$ of FIS and $3.2 \%$ of RIS patients ( $p<0.001)$.

Conclusions. This is the first such comprehensive and long-term analysis of recurrent stroke in Silesia, Poland. It could help in the implementation of appropriate educational programmes, and thus help to improve the health status of society.

Key words: stroke, epidemiology, ischaemic stroke, haemorrhagic stroke, recurrent stroke

(Neurol Neurochir Pol 2019; 53 (4): 277-290)
\end{abstract}

\section{Introduction}

Stroke constitutes the third highest cause of death and the main cause of permanent disability in adults in Europe. Due to its poor prognosis, and the high costs of treatment and of chronic care, stroke is not only a medical but also a social problem.
Recently conducted epidemiological studies have significantly improved our understanding of stroke epidemiology and treatment. But regular updates at local, national and global levels are needed. The first epidemiological data on cerebrovascular diseases in Poland comes from the years 1980-2010 [1-13]. The most recent studies, both national and regional, were conducted in the last decade [14-17]. Some

Address for correspondence: Beata Łabuz-Roszak, Department of Basic Medical Sciences, Faculty of Public Health, Medical University of Silesia, Katowice, Poland, e-mail: beatamaria.pl@hoga.pl 
of them have concerned the Silesian Province, an industrial region of Poland covering 12\% of the nation's population (4.6 million people). In these studies, we have analysed the local incidence of first-ever-stroke (FS), the number of stroke hospitalisations, stroke aetiology, outcome, used methods of diagnostics, and treatment between 2009 and 2015 [15, 16].

However, there is still a lack of recent epidemiological data on recurrent stroke (RS) in Poland despite the fact that this is a known indicator of the effectiveness of secondary stroke prevention.

Therefore, the aim of this study was to assess the epidemiological characteristics of RS in the Silesian Province of Poland over the course of the last decade.

\section{Materials and methods}

Our study was based on data obtained from stroke questionnaires $(n=88,425)$ which were mandatorily reported to the National Health Fund (NHF; the only public health insurer in Poland) by all Silesian hospital departments for stroke patients (homogeneous patient groups: A48-A51). The analysed period was between 2009 and 2015. The study was carried out with the approval of the Silesian division of the NHF and the Consultant in Neurology for the Silesian Province.

The questionnaire was verified for incomplete or recurring data (e.g. recurring records of the same hospitalisation were excluded). Finally, 81,193 stroke questionnaires were enrolled for analysis. A diagnosis of stroke was made according to the International Classification of Diseases version 10 (ICD-10).

The following data from the stroke questionnaires were used in the present study: age, sex, admission date, date of the first occurrence of stroke symptoms, date of death or discharge, number of hospitalisation days, aetiology of ischaemic stroke (IS) (according to the Trial Org 10172 in Acute Stroke Treatment - TOAST), clinical symptoms (consciousness disorders, hemiparesis/hemiplegia, speech disorders, sensory disorders, posterior circle syndrome), secondary stroke prevention (antiplatelets, anticoagulants, antihypertensives), information on referral for vascular intervention due to artery stenosis, and application of recombinant tissue plasminogen activator (rtPA).

The questionnaires also included information as to whether the stroke was classified as first-ever-stroke (FS) or recurrent stroke (RS). FS was diagnosed when the response to the question "Was it your first stroke accident?" was "Yes", and RS when the response was "No".

According to the Bioethics Committee, the study was not a medical experiment. Therefore, no approval of the Committee was required.

Statistical analysis was done using SAS statistical package version 9.4 (SAS Institute Inc., Cary, NC, USA). The level of statistical significance was set at $\mathrm{p}<0.05$.

For nominal data, percentage values were used. The correlation between the nominal variables was verified using the $\chi 2$ test. Normally distributed quantitative data were characterised using the mean and the standard deviation, whereas the median and the interquartile range was used for non-normally distributed data. The verification of the distribution of the variables and the agreement with the normal distribution were made using the Shapiro-Wilk test. The mean difference significance was verified using the Student's t-test for two groups and the ANOVA test for three or more groups. The consistency of the distribution was verified using the Mann-Whitney U test for two groups and the Kruskal-Wallis test for three or more groups for skewed distributions. Multiple comparisons were made based on post-hoc test results for variance analysis (ANOVA) and the Kruskal-Wallis test and with the Holm-Bonferroni correction to assess significance of the percentage difference in cases of three or more groups. The test for trend was also calculated for consecutive years by means of Jonckheere-Terpstra and Cochran-Armitage tests for continuous and categorical variables, respectively.

\section{Results}

Based on analysis of the data obtained from the stroke questionnaires, the number of RS hospitalisations in the Silesian Province between 2009 and 2015 was 18,063 (9,229 women and 8,715 men; $\mathrm{P}<0.001$; in 119 cases sex was not recorded). In 4,763 subjects, the type of stroke (first or recurrent) could not be determined (Tab. 1).

RS constituted $22.2 \%$ of all acute stroke hospitalisations in the analysed period. The number of hospitalisations due to recurrent haemorrhagic stroke (RHS; I60, I61, I62) was 1,619 (15\% of all hospitalisations with acute haemorrhagic stroke i.e. HS diagnosis), while the total number of hospitalisations due to recurrent ischaemic stroke (RIS; I63) was 16,256 (23.4\% all hospitalisations with acute IS diagnosis) (Tab. 3, 4).

The percentage of RS significantly decreased during the period under consideration $(\mathrm{p}<0.001)$. The same observation concerned RIS, but not RHS (Tab. 1, 3, 4).

The median age for patients with RS was 74 (range 66-81) years. The age of male patients (71 (range 63-78) years) was statistically significantly lower $(\mathrm{P}<0.001)$ compared to female patients (78 (70-84) years).

The median age for patients with RIS was 75 (range 66-81) years. The age of male patients (71 (range 63-79) years) was statistically significantly lower $(\mathrm{P}<0.001)$ compared to female patients (78 (range 70-84) years).

The median age for patients with RHS was 72 (range $62-80$ ) years. The age of male patients (69 (range 61-77) years) was statistically significantly lower $(\mathrm{P}<0.001)$ compared to female patients (76 (range 66-82) years) (Tab. 5).

Large-artery atherosclerosis and cardioembolisms were significantly more often recognised in RIS than in first-ever ischaemic stroke (FIS) (consecutively, $38.2 \%$ vs $36.0 \%$, and $21 \%$ vs $18.1 \%$; $\mathrm{p}<0.001)$. On the other hand, lacunar stroke was less 
Table 1. Number of acute (first and recurrent) stroke-related hospitalisations in the Silesian Province between 2009 and 2015 (no data on sex in 487 patients in 2012)

\begin{tabular}{|c|c|c|c|c|}
\hline \multicolumn{2}{|c|}{ Year } & $\begin{array}{c}\text { Number of hospitalisations due } \\
\text { to acute stroke } \\
\mathrm{N}(\%)\end{array}$ & $\begin{array}{l}\text { Number of hospitalisations } \\
\text { in women } \\
\mathbf{N}(\%)\end{array}$ & $\begin{array}{l}\text { Number of hospitalisations } \\
\text { in men } \\
\mathbf{N}(\%)\end{array}$ \\
\hline \multirow[t]{4}{*}{2009} & All & $11,083(100)$ & $5,697(100)$ & $5,386(100)$ \\
\hline & FS & 7,987 (72.1) & $4,061(71.3)$ & $3,926(72.9)$ \\
\hline & RS & 2,559 (23.1) & $1,338(23.5)$ & $1,221(22.7)$ \\
\hline & ND & $537(4.9)$ & $298(5.2)$ & $239(4.4)$ \\
\hline \multirow[t]{4}{*}{2010} & All & $11,751(100)$ & $6,126(100)$ & $5,625(100)$ \\
\hline & FS & $8,598(73.2)$ & 4,465 (72.9) & $4,133(73.5)$ \\
\hline & RS & $2,681(22.8)$ & $1,391(22.7)$ & $1,290(22.9)$ \\
\hline & ND & $472(4)$ & $270(4.4)$ & $202(3.6)$ \\
\hline \multirow[t]{4}{*}{2011} & All & $11,921(100)$ & $6,139(100)$ & $5,782(100)$ \\
\hline & FS & $8,618(72.3)$ & $4,409(71.8)$ & 4,209 (72.8) \\
\hline & RS & $2,789(23.4)$ & $1,443(23.5)$ & $1,346(23.3)$ \\
\hline & ND & $514(4.3)$ & $287(4.7)$ & $227(3.9)$ \\
\hline \multirow[t]{4}{*}{2012} & All & $11,912(100)$ & $5,905(100)$ & $5,520(100)$ \\
\hline & FS & $8,690(72.9)$ & $4,282(72.5)$ & $4,052(73.4)$ \\
\hline & RS & 2,725 (22.9) & $1,350(22.9)$ & $1,256(22.8)$ \\
\hline & ND & $497(4.2)$ & $273(4.6)$ & $212(3.8)$ \\
\hline \multirow[t]{4}{*}{2013} & All & $11,926(100)$ & $6,202(100)$ & $5,724(100)$ \\
\hline & FS & $8,605(72.2)$ & $4,486(72.3)$ & 4,119 (72.0) \\
\hline & RS & $2,668(22.4)$ & $1,368(22.1)$ & $1,300(22.7)$ \\
\hline & ND & $653(5.5)$ & $348(5.6)$ & $305(5.3)$ \\
\hline \multirow[t]{4}{*}{2014} & All & $11,505(100)$ & $5,956(100)$ & $5,549(100)$ \\
\hline & FS & $8,143(70.8)$ & $4,261(71.5)$ & $3,882(70.0)$ \\
\hline & RS & $2,413(21.0)$ & $1,210(20.3)$ & $1,203(21.7)$ \\
\hline & ND & $949(8.3)$ & $485(8.1)$ & $464(8.4)$ \\
\hline \multirow[t]{4}{*}{2015} & All & $11,095(100)$ & $5,671(100)$ & $5,424(100)$ \\
\hline & FS & $7,726(69.6)$ & $3,924(69.2)$ & $3,802(70.1)$ \\
\hline & RS & $2,228(20.1)$ & $1,129(19.9)$ & $1,099(20.3)$ \\
\hline & ND & $1,141(10.3)$ & $618(10.9)$ & $523(9.6)$ \\
\hline \multirow[t]{4}{*}{ All } & All & $81,193(100)$ & $39,010(100)$ & $41,696(100)$ \\
\hline & FS & $58,367(71.9)$ & $28,123(72.1)$ & $29,888(71.7)$ \\
\hline & RS & $18,063(22.2)$ & $8,715(22.3)$ & 9,229 (22.1) \\
\hline & ND & $4,763(5.9)$ & $2,172(5.6)$ & $2,579(6.2)$ \\
\hline \multicolumn{2}{|c|}{$P^{a}$ for trend } & $<0.001$ & $<0.001$ & 0.173 \\
\hline
\end{tabular}

All - all stroke types (160-164); FS - first-ever-stroke; RS - recurrent stroke; ND - no data on type of stroke; ${ }^{\mathrm{a}}$ - Cochran-Armitage test for trend with Holm-Bonferroni correction

often diagnosed in RIS than in FIS $(8.8 \%$ vs $10.0 \%$; $\mathrm{p}<0.001)$. The aetiology of stroke was undetermined in $30.4 \%$ of subjects of RIS compared to $34.1 \%$ of subjects of FIS ( $p<0.001$ ) (Tab. 6). The clinical manifestation of stroke was significantly more expressed in RIS than in FIS ( $p<0.001)$ (Tab. 7).

During the analysed period, the in-hospital mortality rate for RS was $18.4 \%$, and it was significantly higher compared to FS $(17.2 \%)(\mathrm{p}<0.001)$. The same observation was done for RIS vs FIS $(16.2 \%$ vs $13.9 \%$; $\mathrm{p}<0.001)$, and for RHS vs first-ever haemorrhagic stroke (FHS) $(39.8 \%$ vs $36 \% ; \mathrm{p}=0.004)$. The same trend was seen in women and in men (Tab. 8-10).

The median hospitalisation time was 14 (range 5-24) days for RHS, and 11 (range 9-15) days for RIS (Tab. 11). 77.2\% of patients with FS and $78.9 \%$ of patients with RS were admitted to hospital on the day when stroke symptoms appeared $(\mathrm{p}<0.001)$.

The rtPA therapy was applied to 2,598 patients with FIS (5.3\%) and to 525 patients with RIS (3.2\%) treated in hospitals 
Table 2. Rt-PA therapy in patients hospitalised due to first-ever and recurrent ischaemic stroke (163) in the Silesian Province between 2009 and 2015

\begin{tabular}{|c|c|c|c|c|c|c|}
\hline Year & $\begin{array}{l}\text { Number of all } \\
\text { hospitalisations } \\
\text { due to FIS } \\
\text { N }\end{array}$ & $\begin{array}{c}\text { Number of all } \\
\text { hospitalisations } \\
\text { due to RIS } \\
\text { N }\end{array}$ & $\begin{array}{l}\text { Number of all } \\
\text { patients treated } \\
\text { with rt-PA } \\
\text { /percentage of } \\
\text { treated patients } \\
\text { to all patients with } \\
\text { I63 diagnosis / }\end{array}$ & $\begin{array}{l}\text { Number of } \\
\text { patients with FIS } \\
\text { treated with rt-PA } \\
\text { /percentage of } \\
\text { treated patients } \\
\text { to all patients with } \\
\text { FIS diagnosis / }\end{array}$ & $\begin{array}{l}\text { Number of } \\
\text { patients with RIS } \\
\text { treated with rt-PA } \\
\text { /percentage of } \\
\text { treated patients } \\
\text { to all patients with } \\
\text { RIS diagnosis / }\end{array}$ & $\begin{array}{c}\mathrm{P}^{\mathrm{b}} \\
\text { FIS vs RIS treated } \\
\text { with rt-PA }\end{array}$ \\
\hline 2009 & 6,584 & 2,277 & $107 / 1.2 \% /$ & $88(1.3 \%)$ & $17(0.7 \%)$ & 0.025 \\
\hline 2010 & 7,298 & 2,397 & $196 / 1.9 \% /$ & $164(2.2 \%)$ & 27 (1.1\%) & 0.002 \\
\hline 2011 & 7,314 & 2,517 & $296 / 2.9 \% /$ & 242 (3.3\%) & $50(2 \%)$ & 0.002 \\
\hline 2012 & 7,339 & 2,469 & $453 / 4.4 \% /$ & 366 (5\%) & $82(3.3 \%)$ & 0.002 \\
\hline 2013 & 7,353 & 2,422 & $537 / 5.2 \% /$ & 439 (6\%) & 84 (3.5\%) & $<0.001$ \\
\hline 2014 & 6,937 & 2,169 & $806 / 8.2 \% /$ & 620 (8.9\%) & $131(6 \%)$ & $<0.001$ \\
\hline 2015 & 6,600 & 2,005 & 887 (9.3\%) & 679 (10.3\%) & $134(6.7 \%)$ & $<0.001$ \\
\hline$P^{a}$ for trend & - & - & $<0.001$ & $<0.001$ & $<0.001$ & - \\
\hline All & 49,425 & 16,256 & $3,282(4.7 \%)$ & 2,598 (5.3\%) & 525 (3.2\%) & $<0.001$ \\
\hline
\end{tabular}

- Cochran-Armitage test for trend with Holm-Bonferroni correction

${ }^{b}$ - Chi ${ }^{2}$ test with Holm-Bonferroni correction

of the Silesian Province between 2009 and 2015 (p < 0.001) (Tab. 2). The percentage changed between 2009 and 2015 from $1.3 \%$ (FIS) and $0.7 \%$ (RIS) to $10.3 \%$ (FIS) and $6.7 \%$ (RIS).

The overall in-hospital mortality in patients with FIS treated with rtPA ( $\mathrm{n}=396 ; 15.2 \%)$ was not statistically significantly higher compared to the in-hospital mortality of patients with FIS untreated with $\mathrm{rtPA}(\mathrm{n}=6,489 ; 13.9 \%)(\mathrm{P}=0.142)$. Also, the overall in-hospital mortality in patients with RIS treated with rtPA ( $\mathrm{n}=87 ; 16.6 \%)$ was not statistically significantly higher compared to the in-hospital mortality of patients with RIS untreated with rtPA $(\mathrm{n}=2,548 ; 16.2 \%)(\mathrm{P}=0.885)$. No difference was found between the in-hospital mortality of FIS patients and the in-hospital mortality of RIS patients treated with rtPA ( $p=0.885)$. Gender did not influence the in-hospital mortality in patients treated with rtPA (Tab. 12-13).

The in-hospital mortality in patients either with RIS or FIS was significantly higher in cardiogenic stroke compared to atherogenic stroke (Tab. 14-15).

The in-hospital mortality in patients either with FIS or RIS treated with rtPA was not associated with aetiology of stroke (Tab. 16-17).

Data obtained from the stroke questionnaires allowed us to determine the secondary stroke prevention therapy; $81.7 \%$ of RIS patients and $84.3 \%$ of FIS patients ( $p<0.001$ ) were administered antiplatelet drugs, $26.2 \%$ of RIS subjects and $23 \%$ of FIS subjects - oral anticoagulants $(\mathrm{p}<0.001)$, and subsequently, $84.4 \%$ and $79.9 \%$ - antihypertensive drugs ( $\mathrm{p}<$ 0.001) (Tab. 18). Furthermore, $3.4 \%$ of patients with FIS and $3.1 \%$ of patients with RIS were referred for vascular intervention due to artery stenosis.

In patients with cardioembolic stroke aetiology, $37.5 \%$ of subjects with FIS and $40.6 \%$ of subjects with RIS were administered anticoagulants. The percentage of patients with RIS and cardioembolic stroke treated with anticoagulants gradually increased over the subsequent years $(p=0.033)$ while a negative trend was observed for antiplatelet drugs $(\mathrm{p}=0.004)$ (Tab. 19).

\section{Discussion}

As we described in our previous paper, the number of hospitalisations due to stroke and the incidence of first-ever-stroke in the Silesian Province were high (from 169/100,000 in 2009 to $187 / 100,000$ in 2015), and seemed to be more akin to Eastern rather than to Western European countries [15, 18, 19]. This suggests that primary prevention of stroke may be imperfectly implemented in our country, and that the awareness of cerebrovascular risk factors is insufficient.

On the other hand, the number of recurrent strokes is the indictor of the efficiency of secondary prevention. Our study shows that hospitalisations due to recurrent stroke constituted a little more than one fifth of all hospitalisations due to acute stroke. The recurrence is higher in IS than in HS. The selected epidemiological studies show that the risk of recurrence after a first-ever stroke reaches $4 \%$ at 1 month, $13 \%$ at 1 year, and almost $40 \%$ at 10 years [20-24]. Readmission to hospital has a negative effect on the quality of a patient's life and increases socioeconomic costs [25].

We have found that the number of RS has significantly decreased during the last decade (RS constituted 23.1\% of all stroke hospitalisations in 2009 but $20.1 \%$ in 2015; $\mathrm{p}<0.001$ ). In the Warsaw Stroke Registry (conducted in 1991-1992), recurrent strokes constituted $27 \%$ of all acute stroke events observed during the study [2, 3]. In our study, a decreasing number concerned RIS, but not RHS. This is consistent with other studies $[20,26]$. The decreasing number of recurrent strokes could be associated 
Table 3. Number of acute (first and recurrent) ischaemic stroke-related hospitalisations in the Silesian Province between 2009 and 2015

\begin{tabular}{|c|c|c|c|c|}
\hline Year & & $\begin{array}{c}\text { Number of hospitalisations due } \\
\text { to acute stroke } \\
\text { N (\%) }\end{array}$ & $\begin{array}{c}\text { Number of hospitalisations } \\
\text { in women } \\
\text { N (\%) }\end{array}$ & $\begin{array}{l}\text { Number of hospitalisations } \\
\text { in men } \\
\mathbf{N}(\%)\end{array}$ \\
\hline \multirow[t]{4}{*}{2009} & All & $9,275(100)$ & $4,789(100)$ & $4,486(100)$ \\
\hline & FIS & $6,584(71.0)$ & $3,346(69.9)$ & $3,238(72.2)$ \\
\hline & RIS & $2,277(24.5)$ & $1,208(25.2)$ & $1,069(23.8)$ \\
\hline & ND & $414(4.5)$ & $235(4.9)$ & $179(4.0)$ \\
\hline \multirow[t]{4}{*}{2010} & All & $10,058(100)$ & $5,284(100)$ & $4,774(100)$ \\
\hline & FIS & $7,298(72.6)$ & $3,816(72.2)$ & $3,482(72.9)$ \\
\hline & RIS & 2,397 (23.8) & $1,262(23.9)$ & $1,135(23.8)$ \\
\hline & ND & $363(3.6)$ & $206(3.9)$ & $157(3.3)$ \\
\hline \multirow[t]{4}{*}{2011} & All & $10,223(100)$ & $5,303(100)$ & $4,920(100)$ \\
\hline & FIS & $7,314(71.5)$ & $3,764(71.0)$ & $3,550(72.2)$ \\
\hline & RIS & $2,517(24.6)$ & $1,318(24.9)$ & $1,199(24.4)$ \\
\hline & ND & $392(3.8)$ & $221(4.2)$ & $171(3.5)$ \\
\hline \multirow[t]{4}{*}{2012} & All & $10,187(100)$ & $5,078(100)$ & $4,693(100)$ \\
\hline & FIS & $7,339(72.0)$ & $3,632(71.5)$ & 3,407 (72.6) \\
\hline & RIS & $2,469(24.2)$ & $1,232(24.3)$ & $1,129(24.1)$ \\
\hline & ND & $379(3.7)$ & $214(4.2)$ & $157(3.4)$ \\
\hline \multirow[t]{4}{*}{2013} & All & $10,289(100)$ & $5,393(100)$ & $4,896(100)$ \\
\hline & FIS & 7,353 (71.5) & $3,853(71.4)$ & $3,500(71.5)$ \\
\hline & RIS & $2,422(23.5)$ & $1,258(23.3)$ & $1,164(23.8)$ \\
\hline & ND & $514(5)$ & $282(5.2)$ & $232(4.7)$ \\
\hline \multirow[t]{4}{*}{2014} & All & $9,850(100)$ & $5,143(100)$ & $4,707(100)$ \\
\hline & FIS & $6,937(70.4)$ & $3,653(71.0)$ & $3,284(69.8)$ \\
\hline & RIS & $2,169(22.0)$ & $1,104(21.5)$ & 1,065 (22.6) \\
\hline & ND & 744 (7.6) & $386(7.5)$ & $358(7.6)$ \\
\hline \multirow[t]{4}{*}{2015} & All & $9,521(100)$ & $4,890(100)$ & $4,631(100)$ \\
\hline & FIS & $6,600(69.3)$ & $3,368(68.9)$ & 3,232 (69.8) \\
\hline & RIS & $2,005(21.1)$ & $1,012(20.7)$ & $993(21.4)$ \\
\hline & ND & $916(9.6)$ & $5,10(10.4)$ & $406(8.8)$ \\
\hline \multirow[t]{4}{*}{ All } & All & $69,403(100)$ & $35,880(100)$ & $33,107(100)$ \\
\hline & FIS & $49,425(71.2)$ & $25,432(70.9)$ & $23,693(71.6)$ \\
\hline & RIS & $16,256(23.4)$ & $8,394(23.4)$ & $7,754(23.4)$ \\
\hline & ND & $3,722(5.4)$ & $2,054(5.7)$ & $1,660(5.0)$ \\
\hline $\begin{array}{l}P^{a} \text { for } \\
\text { trend }\end{array}$ & & $<0.001$ & $<0.001$ & 0.209 \\
\hline
\end{tabular}

FIS - first-ever ischaemic stroke (163); RIS - recurrent ischaemic stroke (163); ND - no data; - Cochran-Armitage test for trend with Holm-Bonferroni correction

with a better stroke care network and improvements in secondary stroke prevention.

This is also consistent with the observation that the number of stroke survivals with atrial fibrillation on anticoagulants increased from $40 \%$ in 2009 to $44 \%$ in 2015.

As regards the aetiology of RIS, this was undetermined in less than one third of patients (for comparison, in 19911992 this figure was more than half) [2,3]. Such a decrease in unknown aetiology might be the result of a greater availability of diagnostic methods (such as ultrasonography, magnetic resonance, angiography, and broader cardiologic diagnostic possibilities). It is worth emphasising that undetermined RIS was rarer than undetermined FIS (30\% vs 34\%). The most common reason for RIS was large-artery atherosclerosis. Cardioembolisms were responsible for $21 \%$ of RIS (18\% in FIS).

In our study we could not establish the recurrence rates for different subtypes of ischaemic stroke because the findings were anonymous. From the literature, we can see that 
Table 4. Number of acute (first and recurrent) haemorrhagic stroke-related hospitalisations in the Silesian Province between 2009 and 2015

\begin{tabular}{|c|c|c|c|c|}
\hline Year & & $\begin{array}{c}\text { Number of hospitalisations due } \\
\text { to acute stroke } \\
\mathrm{N}(\%)\end{array}$ & $\begin{array}{c}\text { Number of hospitalisations } \\
\text { in women } \\
\mathbf{N}(\%)\end{array}$ & $\begin{array}{l}\text { Number of hospitalisations } \\
\text { in men } \\
\mathbf{N}(\%)\end{array}$ \\
\hline \multirow[t]{4}{*}{2009} & All & $1,604(100)$ & $798(100)$ & 806 (100) \\
\hline & FHS & $1,251(78.0)$ & $629(78.8)$ & 622 (77.2) \\
\hline & RHS & $246(15.3)$ & $115(14.4)$ & $131(16.3)$ \\
\hline & ND & $107(6.7)$ & $54(6.8)$ & $53(6.6)$ \\
\hline \multirow[t]{4}{*}{2010} & All & $1,578(100)$ & $783(100)$ & 795 (100) \\
\hline & FHS & $1,219(77.3)$ & $608(77.7)$ & $611(76.9)$ \\
\hline & RHS & $255(16.2)$ & $113(14.4)$ & $142(17.9)$ \\
\hline & ND & $104(6.6)$ & $62(7.9)$ & $42(5.3)$ \\
\hline \multirow[t]{4}{*}{2011} & All & $1,562(100)$ & 747 (100) & $815(100)$ \\
\hline & FHS & $1,211(77.5)$ & $583(78.1)$ & $628(77.1)$ \\
\hline & RHS & $245(15.7)$ & $108(14.5)$ & $137(16.8)$ \\
\hline & ND & $106(6.8)$ & $56(7.5)$ & $50(6.1)$ \\
\hline \multirow[t]{4}{*}{2012} & All & $1,596(100)$ & $761(100)$ & $771(100)$ \\
\hline & FHS & $1,260(79.0)$ & $604(79.4)$ & $605(78.5)$ \\
\hline & RHS & $233(14.6)$ & $104(13.7)$ & $119(15.4)$ \\
\hline & $\mathrm{Na}^{\prime} \mathrm{s}$ & $103(6.5)$ & $53(7.0)$ & $47(6.1)$ \\
\hline \multirow[t]{4}{*}{2013} & All & $1,518(100)$ & $740(100)$ & $778(100)$ \\
\hline & FHS & $1,169(77.0)$ & $584(78.9)$ & $585(75.2)$ \\
\hline & RHS & $220(14.5)$ & $97(13.1)$ & $123(15.8)$ \\
\hline & $\mathrm{Na}^{\prime} \mathrm{s}$ & $129(8.5)$ & $59(8.0)$ & $70(9.0)$ \\
\hline \multirow[t]{4}{*}{2014} & All & $1,531(100)$ & $740(100)$ & $791(100)$ \\
\hline & FHS & $1,125(73.5)$ & $557(75.3)$ & $568(71.8)$ \\
\hline & RHS & 219 (14.3) & $94(12.7)$ & $125(15.8)$ \\
\hline & $\mathrm{Na}^{\prime} \mathrm{s}$ & $187(12.2)$ & $89(12.0)$ & $98(12.4)$ \\
\hline \multirow[t]{4}{*}{2015} & All & $1,439(100)$ & $711(100)$ & $728(100)$ \\
\hline & FHS & $1,038(72.1)$ & $511(71.9)$ & $527(72.4)$ \\
\hline & RHS & $201(14.0)$ & $105(14.8)$ & $96(13.2)$ \\
\hline & $\mathrm{Na}^{\prime} \mathrm{s}$ & $200(13.9)$ & $95(13.4)$ & $105(14.4)$ \\
\hline \multirow[t]{4}{*}{ All } & All & $10,828(100)$ & $5,280(100)$ & $5,484(100)$ \\
\hline & FHS & $8,273(76.4)$ & $4,076(77.2)$ & $4,146(75.6)$ \\
\hline & RHS & $1,619(15.0)$ & $736(13.9)$ & $873(15.9)$ \\
\hline & $\mathrm{Na} \mathbf{s}$ & $936(8.6)$ & $468(8.9)$ & $465(8.5)$ \\
\hline $\begin{array}{l}P^{a} \text { for } \\
\text { trend }\end{array}$ & & 0.476 & 0.957 & 0.305 \\
\hline
\end{tabular}

FHS - first-ever haemorrhagic stroke (160-162); RHS - recurrent haemorrhagic stroke (160-162); ND - no data; ${ }^{a}$ - Cochran-Armitage test for trend with Holm-Bonferroni correction

the 3-month recurrence rates are higher for stroke caused by large artery atherosclerosis (14.3\%) than for cardioembolic stroke (7.7\%), lacunar stroke (2\%) and ischaemic stroke due to undetermined causes (5.6\%) [27]. A 23-year longitudinal population-based study showed that the implementation of a stroke care network and good primary prevention are defined areas associated with a decrease in the number of recurrent strokes [26].
The clinical symptoms were significantly more expressed in RIS than in FIS. Similarly to other authors, we found that hemiparesis/hemiplegia and speech disorders were the most common presenting symptoms [28].

The median length of hospital stay was 11 (range 9-15) days for RIS and 14 (range 5-24) days for RHS, both shorter than previously described [29]. Hospitalisation time was similar for RIS and FIS, but longer for RHS than for FHS. 
Table 5. Median (Q1-Q3) age of patients with stroke in the analysed period

\begin{tabular}{|c|c|c|c|c|c|c|c|c|c|}
\hline Year & FS & RS & $\mathbf{P}^{\mathbf{a}}$ & FIS & RIS & $\mathbf{P}^{\mathbf{a}}$ & FHS & RHS & $\mathbf{P}^{\mathbf{a}}$ \\
\hline 2009 & $72(62-80)$ & $74(66-81)$ & $<0.001$ & $73(63-80)$ & $75(66-81)$ & $<0.001$ & $70(56-78)$ & $73(63-80)$ & $<0.001$ \\
\hline 2010 & $72(62-80)$ & $74(65-81)$ & $<0.001$ & $73(62-80)$ & $74(65-81)$ & $<0.001$ & $68(56-79)$ & $72(62-79)$ & 0.009 \\
\hline 2011 & $73(62-81)$ & $74(65-81)$ & $<0.001$ & $73(63-81)$ & $74(65-81)$ & $<0.001$ & $68(57-79)$ & $71(62-80)$ & 0.012 \\
\hline 2012 & $73(62-81)$ & $74(65-81)$ & $<0.001$ & $73(63-81)$ & $75(65-81)$ & $<0.001$ & $67(56-78)$ & $70(61-78)$ & 0.004 \\
\hline 2013 & $73(63-81)$ & $74(65.5-81)$ & $<0.001$ & $73(63-81)$ & $74(66-82)$ & $<0.001$ & 70 (59-79) & $72(61-79)$ & 0.139 \\
\hline 2014 & $73(63-81)$ & $75(66-82)$ & $<0.001$ & $73(64-82)$ & $75(66-82)$ & $<0.001$ & 70 (59-79) & $73(64-80)$ & 0.003 \\
\hline 2015 & $73(63-81)$ & $75(66-82)$ & $<0.001$ & $73(64-81)$ & $75(67-83)$ & $<0.001$ & $70(59-80)$ & $74(65-80)$ & 0.001 \\
\hline$P^{b}$ for trend & $<0.001$ & $<0.001$ & - & $<0.001$ & $<0.001$ & - & 0.001 & 0.206 & - \\
\hline All & $73(62-81)$ & $74(66-81)$ & $<0.001$ & $73(63-81)$ & $75(66-81)$ & $<0.001$ & $69(57-79)$ & $72(62-80)$ & $<0.001$ \\
\hline
\end{tabular}

- U Mann-Whitney test;

- Jonckheere-Terpstra test for trend with Holm-Bonferroni correction

FS - first-ever stroke; RS - recurrent stroke;

FIS - first-ever ischaemic stroke (163); RIS - recurrent ischaemic stroke (163);

FHS - first-ever haemorrhagic stroke (160-162); RHS - recurrent haemorrhagic stroke (160-162)

Table 6. Aetiology of ischaemic stroke in the Silesian Province between 2009 and 2015, according to the TOAST classification

\begin{tabular}{|c|c|c|c|c|c|c|c|}
\hline \multirow[t]{2}{*}{ Year } & & \multicolumn{5}{|c|}{ Aetiology of ischaemic stroke } & \multirow[t]{2}{*}{$\mathbf{P}^{\mathbf{a}}$} \\
\hline & & $\begin{array}{l}\text { Large-artery at- } \\
\text { herosclerosis }\end{array}$ & $\begin{array}{l}\text { Cardio- } \\
\text {-embolism }\end{array}$ & $\begin{array}{c}\text { Small-vessel } \\
\text { occlusion (lacune) }\end{array}$ & $\begin{array}{l}\text { Other determined } \\
\text { aetiology }\end{array}$ & $\begin{array}{l}\text { Undetermined } \\
\text { aetiology }\end{array}$ & \\
\hline \multirow[t]{2}{*}{2009} & FIS & $2,502(38.0 \%)$ & $1,026(15.6 \%)$ & $683(10.4 \%)$ & $141(2.1 \%)$ & $2,232(33.9 \%)$ & $<0.001$ \\
\hline & RIS & $875(38.4 \%)$ & 455 (20.0\%) & $215(9.4 \%)$ & $34(1.5 \%)$ & $698(30.7 \%)$ & \\
\hline \multirow[t]{2}{*}{2010} & FIS & $2,672(36.6 \%)$ & $1,093(15.0 \%)$ & $642(8.8 \%)$ & $111(1.5 \%)$ & $2,780(38.1 \%)$ & $<0.001$ \\
\hline & RIS & $912(38.1 \%)$ & $463(19.3 \%)$ & $177(7.4 \%)$ & $35(1.5 \%)$ & $810(33.8 \%)$ & \\
\hline \multirow[t]{2}{*}{2011} & FIS & $2,579(35.3 \%)$ & $1,348(18.4 \%)$ & 699 (9.6\%) & $110(1.5 \%)$ & $2,578(35.3 \%)$ & $<0.001$ \\
\hline & RIS & $988(39.3 \%)$ & $512(20.3 \%)$ & $230(9.1 \%)$ & $24(1.0 \%)$ & $763(30.3 \%)$ & \\
\hline \multirow[t]{2}{*}{2012} & FIS & $2,720(37.1 \%)$ & $1,473(20.1 \%)$ & $713(9.7 \%)$ & $135(1.8 \%)$ & $2,298(31.3 \%)$ & 0.004 \\
\hline & RIS & $943(38.2 \%)$ & $555(22.5 \%)$ & $187(7.6 \%)$ & $49(2.0 \%)$ & $735(29.8 \%)$ & \\
\hline \multirow[t]{2}{*}{2013} & FIS & $2,540(34.5 \%)$ & $1,395(19.0 \%)$ & $778(10.6 \%)$ & $126(1.7 \%)$ & $2,514(34.2 \%)$ & $<0.001$ \\
\hline & RIS & $919(37.9 \%)$ & 539 (22.3\%) & $220(9.1 \%)$ & $33(1.4 \%)$ & 711 (29.4\%) & \\
\hline \multirow[t]{2}{*}{2014} & FIS & 2,407 (34.7\%) & $1,312(18.9 \%)$ & $738(10.6 \%)$ & $166(2.4 \%)$ & 2,314 (33.4\%) & 0.001 \\
\hline & RIS & $824(38.0 \%)$ & 454 (20.9\%) & 211 (9.7\%) & $35(1.6 \%)$ & $645(29.7 \%)$ & \\
\hline \multirow[t]{2}{*}{2015} & FIS & 2,388 (36.2\%) & 1,276 (19.3\%) & $675(10.2 \%)$ & 125 (1.9\%) & $2,136(32.4 \%)$ & 0.010 \\
\hline & RIS & 751 (37.5\%) & 442 (22.0\%) & 191 (9.5\%) & $42(2.1 \%)$ & $579(28.9 \%)$ & \\
\hline$P^{b}$ for trend & & 0.289 & $<0.001$ & 0.626 & 0.751 & 0.082 & - \\
\hline \multirow[t]{2}{*}{ Total } & FIS & $17,808(36.0 \%)$ & $8,923(18.1 \%)$ & 4,928 (10.0\%) & 914 (1.9\%) & $16,852(34.1 \%)$ & $<0.001$ \\
\hline & RIS & 6,212 (38.2\%) & $3,420(21.0 \%)$ & $1,431(8.8 \%)$ & $252(1.6 \%)$ & 4,941 (30.4\%) & \\
\hline
\end{tabular}

- Chi $i^{2}$ test with Holm-Bonferroni correction

- Cochran-Armitage test for trend with Holm-Bonferroni correction

FIS - first-ever ischaemic stroke (163); RIS - recurrent ischaemic stroke (163)

Table 7. Clinical symptoms of acute stroke in the Silesian Province between 2009 and 2015

\begin{tabular}{lcccc|} 
& $\begin{array}{c}\text { ALL STROKES } \\
\mathbf{( 1 6 0 - 1 6 4 )}\end{array}$ & $\begin{array}{c}\text { FS } \\
(\mathbf{I 6 0 - 1 6 4 )}\end{array}$ & $\begin{array}{c}\text { RS } \\
\mathbf{( 1 6 0 - 1 6 4 )}\end{array}$ & P \\
\hline Consciousness disorders & $26,302(34.4 \%)$ & $19,301(33.1 \%)$ & $7,001(38.8 \%)$ & $<0.001$ \\
Hemiparesis/ hemiplegia & $61,984(81.1 \%)$ & $46,670(80.0 \%)$ & $15,314(84.8 \%)$ & $<0.001$ \\
Speech disorders & $45,117(59.0 \%)$ & $33,221(56.9 \%)$ & $11,896(65.9 \%)$ & $<0.001$ \\
Sensation disorders & $25,026(32.7 \%)$ & $18,735(32.1 \%)$ & $6,291(34.8 \%)$ & $<0.001$ \\
Posterior circle syndrome & $17,180(22.5 \%)$ & $12,943(22.2 \%)$ & $4,237(23.5 \%)$ & $<0.001$
\end{tabular}


Table 8. In-hospital mortality in acute first-ever and recurrent stroke in the Silesian Province between 2009 and 2015. Data presented as the number and percentage of deaths, $\mathrm{n}(\%)$

\begin{tabular}{llllllllll} 
Year & $\begin{array}{c}\text { Overall ho- } \\
\text { spital morta- } \\
\text { lity in FS }\end{array}$ & $\begin{array}{c}\text { Overall ho- } \\
\text { spital morta- } \\
\text { lity in RS }\end{array}$ & $\begin{array}{c}\text { PS vs } \\
\text { RS }\end{array}$ & $\begin{array}{c}\text { Mortality } \\
\text { in FIS }\end{array}$ & $\begin{array}{c}\text { Mortality } \\
\text { in RIS }\end{array}$ & $\begin{array}{c}\text { P } \\
\text { FIS vs } \\
\text { RIS }\end{array}$ & $\begin{array}{c}\text { Mortality } \\
\text { in FHS }\end{array}$ & $\begin{array}{c}\text { Mortality } \\
\text { in RHS }\end{array}$ & $\begin{array}{c}\text { P } \\
\text { FHS vs } \\
\text { RHS }\end{array}$ \\
\hline 2009 & $1,440(18.0 \%)$ & $510(19.9 \%)$ & 0.187 & $954(14.5 \%)$ & $396(17.4 \%)$ & 0.005 & $410(32.8 \%)$ & $99(40.2 \%)$ & 0.166 \\
2010 & $1,460(17.0 \%)$ & $519(19.4 \%)$ & 0.033 & $1,010(13.8 \%)$ & $405(16.9 \%)$ & 0.002 & $435(35.7 \%)$ & $110(43.1 \%)$ & 0.166 \\
2011 & $1,523(17.7 \%)$ & $521(18.7 \%)$ & 0.696 & $1,074(14.7 \%)$ & $420(16.7 \%)$ & 0.047 & $422(34.8 \%)$ & $93(38.0 \%)$ & 1.000 \\
2012 & $1,468(16.9 \%)$ & $491(18.0 \%)$ & 0.696 & $1,004(13.7 \%)$ & $395(16.0 \%)$ & 0.018 & $454(36.0 \%)$ & $94(40.3 \%)$ & 1.000 \\
2013 & $1,459(17.0 \%)$ & $459(17.2 \%)$ & 1.000 & $994(13.5 \%)$ & $363(15.0 \%)$ & 0.139 & $452(38.7 \%)$ & $87(39.5 \%)$ & 1.000 \\
2014 & $1,342(16.5 \%)$ & $432(17.9 \%)$ & 0.504 & $910(13.1 \%)$ & $338(15.6 \%)$ & 0.018 & $419(37.2 \%)$ & $91(41.6 \%)$ & 1.000 \\
2015 & $1,340(17.3 \%)$ & $394(17.7 \%)$ & 1.000 & $939(14.2 \%)$ & $318(15.9 \%)$ & 0.139 & $384(37.0 \%)$ & $70(34.8 \%)$ & 1.000 \\
$P^{b}$ for trend & 0.261 & 0.035 & - & 0.261 & 0.105 & - & 0.035 & 0.0321 & - \\
All & $10,032(17.2 \%)$ & $3,326(18.4 \%)$ & $<0.001$ & $6,885(13.9 \%)$ & $2,635(16.2 \%)$ & $<0.001$ & $2,976(36.0 \%)$ & $644(39.8 \%)$ & 0.004
\end{tabular}

FIS - first-ever ischaemic stroke (163); RIS - recurrent ischaemic stroke (163);

FHS - first-ever haemorrhagic stroke (160-162); RHS - recurrent haemorrhagic stroke (160-162)

Data presented as $\mathrm{N}(\%)$
- Chi' test with Holm-Bonferroni correction

${ }^{b}$ - Cochran-Armitage test for trend with Holm-Bonferroni correction (level of significance for trend in in-hospital mortality between 2009 and 2015)

Table 9. In-hospital mortality in acute first-ever and recurrent stroke in women in the Silesian Province between 2009 and 2015. Data presented as the number and percentage of deaths, $\mathrm{n}(\%)$

\begin{tabular}{lccccccccc} 
Year & $\begin{array}{c}\text { Overall female } \\
\text { hospital mor- } \\
\text { tality in FS }\end{array}$ & $\begin{array}{c}\text { Overall female } \\
\text { hospital mor- } \\
\text { tality in RS }\end{array}$ & $\begin{array}{c}\text { F } \\
\text { FS vs }\end{array}$ & $\begin{array}{c}\text { Mortality } \\
\text { in FIS }\end{array}$ & $\begin{array}{c}\text { Mortality } \\
\text { in RIS }\end{array}$ & $\begin{array}{c}\text { P } \\
\text { FIS vs } \\
\text { RIS }\end{array}$ & $\begin{array}{c}\text { Mortality } \\
\text { in FHS }\end{array}$ & $\begin{array}{c}\text { Mortality } \\
\text { in RHS }\end{array}$ & $\begin{array}{c}\text { P } \\
\text { FHS vs } \\
\text { RHS }\end{array}$ \\
\hline 2009 & $804(19.8 \%)$ & $271(20.3 \%)$ & 1.000 & $539(16.1 \%)$ & $226(18.7 \%)$ & 0.172 & $220(35.0 \%)$ & $42(36.5 \%)$ & 1.000 \\
2010 & $812(18.2 \%)$ & $283(20.3 \%)$ & 0.499 & $590(15.5 \%)$ & $229(18.1 \%)$ & 0.172 & $215(35.4 \%)$ & $52(46.0 \%)$ & 0.219 \\
2011 & $849(19.3 \%)$ & $294(20.4 \%)$ & 1.000 & $607(16.1 \%)$ & $248(18.8 \%)$ & 0.172 & $219(37.6 \%)$ & $41(38.0 \%)$ & 1.000 \\
2012 & $782(18.3 \%)$ & $256(19.0 \%)$ & 1.000 & $558(15.4 \%)$ & $222(18.0 \%)$ & 0.172 & $218(36.1 \%)$ & $34(32.7 \%)$ & 1.000 \\
2013 & $822(18.3 \%)$ & $253(18.5 \%)$ & 1.000 & $589(15.3 \%)$ & $201(16.0 \%)$ & 1.000 & $226(38.7 \%)$ & $47(48.5 \%)$ & 0.36 \\
2014 & $757(17.8 \%)$ & $227(18.8 \%)$ & 1.000 & $543(14.9 \%)$ & $181(16.4 \%)$ & 0.644 & $204(36.6 \%)$ & $44(46.8 \%)$ & 0.36 \\
2015 & $760(19.4 \%)$ & $212(18.8 \%)$ & 1.000 & $549(16.3 \%)$ & $169(16.7 \%)$ & 1.000 & $202(39.5 \%)$ & $40(38.1 \%)$ & 1.000 \\
$P^{b}$ for trend & 0.977 & 0.492 & - & 1.000 & 0.202 & - & 0.492 & 1.000 & - \\
All & $5,586(18.7 \%)$ & $1,796(19.5 \%)$ & 0.098 & $3,975(15.6 \%)$ & $1,476(17.6 \%)$ & $<0.001$ & $1,504(36.9 \%)$ & $300(40.8 \%)$ & 0.046
\end{tabular}

FIS - first-ever ischaemic stroke (163); RIS - recurrent ischaemic stroke (163);

FHS - first-ever haemorrhagic stroke (I60-162); RHS - recurrent haemorrhagic stroke (160-162)

Data presented as $\mathrm{N}(\%)$

- Chi test with Holm-Bonferroni correction

${ }^{\mathrm{b}}$ - Cochran-Armitage test for trend with Holm-Bonferroni correction (level of significance for trend in in-hospital mortality between 2009 and 2015)

Table 10. In-hospital mortality in acute first-ever and reccurent stroke in men in the Silesian Province between 2009 and 2015. Data presented as the number and percentage of deaths, $\mathrm{n}(\%)$

\begin{tabular}{lccccccccc} 
Year & $\begin{array}{c}\text { Overall male } \\
\text { hospital mor- } \\
\text { tality in FS }\end{array}$ & $\begin{array}{c}\text { Overall male } \\
\text { hospital mor- } \\
\text { tality in RS }\end{array}$ & $\begin{array}{c}\mathbf{P}^{\mathbf{a}} \\
\text { FS vs }\end{array}$ & $\begin{array}{c}\text { Mortality } \\
\text { RS FIS }\end{array}$ & $\begin{array}{c}\text { Mortality } \\
\text { in RIS }\end{array}$ & $\begin{array}{c}\text { P } \\
\text { FIS vs } \\
\text { RIS }\end{array}$ & $\begin{array}{c}\text { Mortality } \\
\text { in FHS }\end{array}$ & $\begin{array}{c}\text { Mortality in } \\
\text { RHS }\end{array}$ & $\begin{array}{c}\text { P } \\
\text { FHS vs } \\
\text { RHS }\end{array}$ \\
\hline 2009 & $636(16.2 \%)$ & $239(19.6 \%)$ & 0.043 & $415(12.8 \%)$ & $170(15.9 \%)$ & 0.053 & $190(30.5 \%)$ & $57(43.5 \%)$ & 0.029 \\
2010 & $648(15.7 \%)$ & $236(18.3 \%)$ & 0.158 & $420(12.1 \%)$ & $176(15.5 \%)$ & 0.016 & $220(36.0 \%)$ & $58(40.8 \%)$ & 1.000 \\
2011 & $674(16.0 \%)$ & $227(16.9 \%)$ & 0.921 & $467(13.2 \%)$ & $172(14.3 \%)$ & 0.296 & $203(32.3 \%)$ & $52(38.0 \%)$ & 1.000 \\
2012 & $629(15.5 \%)$ & $217(17.3 \%)$ & 0.552 & $410(12.0 \%)$ & $159(14.1 \%)$ & 0.143 & $216(35.7 \%)$ & $56(47.1 \%)$ & 0.116 \\
2013 & $637(15.5 \%)$ & $206(15.8 \%)$ & 0.921 & $405(11.6 \%)$ & $162(13.9 \%)$ & 0.102 & $226(38.6 \%)$ & $40(32.5 \%)$ & 1.000 \\
2014 & $585(15.1 \%)$ & $205(17.0 \%)$ & 0.496 & $367(11.2 \%)$ & $157(14.7 \%)$ & 0.013 & $215(37.9 \%)$ & $47(37.6 \%)$ & 1.000 \\
2015 & $580(15.3 \%)$ & $182(16.6 \%)$ & 0.879 & $390(12.1 \%)$ & $149(15.0 \%)$ & 0.061 & $182(34.5 \%)$ & $30(31.3 \%)$ & 1.000 \\
Pb for trend $^{0.267}$ & 0.267 & 0.165 & - & 0.198 & 0.400 & - & 0.165 & 0.198 & - \\
All & $4,389(15.6 \%)$ & $1,512(17.4 \%)$ & $<0.001$ & $2,874(12.1 \%)$ & $1,145(14.8 \%)$ & $<0.001$ & $1,452(35.0 \%)$ & $340(39.0 \%)$ & 0.028
\end{tabular}

FIS - first-ever ischaemic stroke (I63); RIS - recurrent ischaemic stroke (163);

FHS - first-ever haemorrhagic stroke (160-162); RHS - recurrent haemorrhagic stroke (160-162)

Data presented as $\mathrm{N}(\%)$

- Chi' test with Holm-Bonferroni correction

b - Cochran-Armitage test for trend with Holm-Bonferroni correction (level of significance for trend in in-hospital mortality between 2009 and 2015) 
Table 11. Hospitalisation time of patients with first-ever and recurrent stroke in the Silesian Province between 2009 and 2015. Data presented as median (Q1-Q3) in days

\begin{tabular}{lccccccccc} 
Year & FS & RS & $\mathbf{p}^{\mathrm{a}}$ & FIS & RIS & $\mathbf{p}^{\mathrm{a}}$ & FHS \\
\hline 2009 & $11(9-17)$ & $11(9-17)$ & 0.463 & $11(9-16)$ & $11(9-16)$ & 0.692 & $13(3-25)$ & $14(6-27)$ & 0.047 \\
2010 & $11(9-17)$ & $11(9-16)$ & 0.347 & $11(9-16)$ & $11(9-16)$ & 0.564 & $14(3-25)$ & $13(4-22)$ & 0.453 \\
2011 & $11(9-16)$ & $11(9-17)$ & 0.161 & $11(9-15)$ & $11(9-16)$ & 0.374 & $13(3-24)$ & $15(5-24)$ & 0.134 \\
2012 & $11(9-16)$ & $11(9-15)$ & 0.934 & $10(9-15)$ & $11(9-15)$ & 0.935 & $12(3-23)$ & $12(5-23)$ & 0.366 \\
2013 & $11(9-15)$ & $11(9-15)$ & 0.439 & $10(9-15)$ & $11(9-15)$ & 0.482 & $13(3-23)$ & $13(4-24)$ & 0.197 \\
2014 & $11(9-16)$ & $11(9-16)$ & 0.112 & $11(9-15)$ & $11(9-15)$ & 0.255 & $14(4-24)$ & $15(8-24)$ & 0.073 \\
2015 & $10(9-15)$ & $11(9-15)$ & 0.252 & $10(9-14)$ & $10(9-15)$ & 0.724 & $12(3-22)$ & $15(5-22)$ & 0.151 \\
P b & $<0.001$ & 0.116 & - & $<0.001$ & 0.015 & - & 0.946 & 0.946 & - \\
All & $11(9-16)$ & $11(9-16)$ & 0.073 & $11(9-15)$ & $11(9-15)$ & 0.437 & $13(3-24)$ & $14(5-24)$ & 0.002
\end{tabular}

- U Mann-Whitney test

- Jonckheere-Terpstra test for trend with Holm-Bonferroni correction

Table 12. In-hospital mortality in patients treated with intravenous thrombolytic therapy (rt-PA) compared to in-hospital mortality in patients untreated with rt-PA in the Silesian Province between 2009 and 2015

\begin{tabular}{lccccccc}
\multicolumn{1}{|c}{ Year } & $\begin{array}{c}\text { Mortality in } \\
\text { FIS treated } \\
\text { with rt-PA }\end{array}$ & $\begin{array}{c}\text { Mortality in } \\
\text { FIS untreated } \\
\text { with rt-PA }\end{array}$ & $\begin{array}{c}\text { P } \\
\text { Treated vs } \\
\text { untreated FIS }\end{array}$ & $\begin{array}{c}\text { Mortality in } \\
\text { RIS treated } \\
\text { with rt-PA }\end{array}$ & $\begin{array}{c}\text { Mortality in } \\
\text { RIS untreated } \\
\text { with rt-PA }\end{array}$ & $\begin{array}{c}\text { P } \\
\text { Treated vs } \\
\text { untreated RIS }\end{array}$ & $\begin{array}{c}\text { Treated FIS vs } \\
\text { treated RIS }\end{array}$ \\
\hline 2009 & $21(23.9 \%)$ & $933(14.4 \%)$ & 0.071 & $3(17.6 \%)$ & $393(17.4 \%)$ & 1.000 & 1.000 \\
2010 & $23(14.0 \%)$ & $987(13.8 \%)$ & 1.000 & $4(14.8 \%)$ & $401(16.9 \%)$ & 1.000 & 1.000 \\
2011 & $33(13.6 \%)$ & $1,041(14.7 \%)$ & 1.000 & $7(14.0 \%)$ & $413(16.7 \%)$ & 1.000 & 1.000 \\
2012 & $53(14.5 \%)$ & $951(13.6 \%)$ & 1.000 & $13(15.9 \%)$ & $382(16.0 \%)$ & 1.000 & 1.000 \\
2013 & $56(12.8 \%)$ & $938(13.6 \%)$ & 1.000 & $12(14.3 \%)$ & $351(15.0 \%)$ & 1.000 & 1.000 \\
2014 & $104(16.8 \%)$ & $806(12.8 \%)$ & 0.033 & $21(16.0 \%)$ & $317(15.6 \%)$ & 1.000 & 1.000 \\
2015 & $106(15.6 \%)$ & $833(14.1 \%)$ & 1.000 & $27(20.1 \%)$ & $291(15.6 \%)$ & 1.000 & 1.000 \\
Pa for trend & 0.982 & 0.173 & - & 0.739 & 0.060 & - & - \\
All & $396(15.2 \%)$ & $6,489(13.9 \%)$ & 0.142 & $87(16.6 \%)$ & $2,548(16.2 \%)$ & 0.885 & 0.885
\end{tabular}

- Chi' test with Holm-Bonferroni correction

Table 13. Comparison of in-hospital mortality in men treated with intravenous thrombolytic therapy (rt-PA) to in-hospital mortality in women treated with rt-PA in the Silesian Province between 2009 and 2015

\begin{tabular}{|c|c|c|c|c|c|c|}
\hline Year & $\begin{array}{l}\text { Mortality in men in } \\
\text { FIS treated with rt-PA }\end{array}$ & $\begin{array}{c}\text { Mortality in women } \\
\text { in FIS treated with } \\
\text { rt-PA }\end{array}$ & $\begin{array}{c}P \\
\text { F vs M }\end{array}$ & $\begin{array}{l}\text { Mortality in men } \\
\text { in RIS treated with } \\
\text { rt-PA }\end{array}$ & $\begin{array}{c}\text { Mortality in women } \\
\text { in RIS treated with } \\
\text { rt-PA }\end{array}$ & $\begin{array}{c}P \\
\text { F vs M }\end{array}$ \\
\hline 2009 & $9(22.0 \%)$ & $12(25.5 \%)$ & 1.000 & $3(30.0 \%)$ & $0(0 \%)$ & 0.772 \\
\hline 2010 & $13(14.3 \%)$ & 10 (13.7\%) & 1.000 & $1(10.0 \%)$ & $3(17.6 \%)$ & 1.000 \\
\hline 2011 & $22(15.8 \%)$ & $11(10.7 \%)$ & 1.000 & $3(12.5 \%)$ & $4(15.4 \%)$ & 1.000 \\
\hline 2012 & $26(13.9 \%)$ & $24(15.2 \%)$ & 1.000 & $8(17.8 \%)$ & $5(16.1 \%)$ & 1.000 \\
\hline 2013 & $24(10.5 \%)$ & 32 (15.2\%) & 0.949 & $4(9.8 \%)$ & $8(18.6 \%)$ & 1.000 \\
\hline 2014 & 55 (16.9\%) & 49 (16.6\%) & 1.000 & $9(13.6 \%)$ & $12(18.5 \%)$ & 1.000 \\
\hline 2015 & $52(15.3 \%)$ & 54 (15.9\%) & 1.000 & $18(24.7 \%)$ & $9(14.8 \%)$ & 0.928 \\
\hline$P^{a}$ for trend & 1.000 & 1.000 & - & 1.000 & 1.000 & - \\
\hline All & 201 (14.9\%) & $192(15.7 \%)$ & 0.570 & $46(17.1 \%)$ & 41 (16.4\%) & 0.831 \\
\hline
\end{tabular}


Table 14. In-hospital mortality (n, \%) in association with the aetiology of FIS in the Silesian Province between 2009 and 2015

\begin{tabular}{lcccccc}
\multicolumn{1}{c}{ Year } & \multicolumn{3}{c}{ Atiology of ischaemic stroke } & & $\mathbf{P}^{\mathrm{a}}$ \\
Large-artery & Cardio-embolism & $\begin{array}{c}\text { Small-vessel } \\
\text { atherosclerosis }\end{array}$ & & $\begin{array}{c}\text { Other determined } \\
\text { aetiology }\end{array}$ & $\begin{array}{c}\text { Undetermined } \\
\text { aetiology }\end{array}$ \\
\hline 2009 & $344(13.8 \%)$ & $196(19.1 \%)$ & $15(2.2 \%)$ & $18(12.8 \%)$ & $381(17.1 \%)$ & $<0.001$ \\
2010 & $359(13.4 \%)$ & $194(17.8 \%)$ & $22(3.4 \%)$ & $13(11.7 \%)$ & $422(15.2 \%)$ & $<0.001$ \\
2011 & $327(12.7 \%)$ & $299(22.2 \%)$ & $32(4.6 \%)$ & $15(13.6 \%)$ & $401(15.6 \%)$ & $<0.001$ \\
2012 & $375(13.8 \%)$ & $262(17.8 \%)$ & $31(4.4 \%)$ & $13(9.6 \%)$ & $323(14.1 \%)$ & $<0.001$ \\
2013 & $338(13.3 \%)$ & $262(18.8 \%)$ & $47(6 \%)$ & $6(4.8 \%)$ & $341(13.6 \%)$ & $<0.001$ \\
2014 & $287(11.9 \%)$ & $233(17.8 \%)$ & $36(4.9 \%)$ & $14(8.4 \%)$ & $340(14.7 \%)$ & $<0.001$ \\
2015 & $330(13.8 \%)$ & $226(17.7 \%)$ & $48(7.1 \%)$ & $20(16.0 \%)$ & $315(14.8 \%)$ & $<0.001$ \\
$\mathrm{P}^{\mathrm{b}}$ for trend & 1.000 & 0.468 & $<0.001$ & 1.000 & 0.045 & - \\
Total & $2.360(13.3 \%)$ & $1.672(18.7 \%)$ & $231(4.7 \%)$ & $99(10.8 \%)$ & $2.523(15 \%)$
\end{tabular}

a - Chi test with Holm-Bonferroni correction

b- Cochran-Armitage test for trend with Holm-Bonferroni correction

Table 15. In-hospital mortality $(n, \%)$ in association with the aetiology of RIS in the Silesian Province between 2009 and 2015

\begin{tabular}{|c|c|c|c|c|c|c|}
\hline \multirow[t]{2}{*}{ Year } & \multicolumn{5}{|c|}{ Aetiology of ischaemic stroke } & \multirow[t]{2}{*}{$\mathbf{P}^{\mathbf{a}}$} \\
\hline & $\begin{array}{l}\text { Large-artery } \\
\text { atherosclerosis }\end{array}$ & Cardio-embolism & $\begin{array}{c}\text { Small-vessel } \\
\text { occlusion (lacune) }\end{array}$ & $\begin{array}{l}\text { Other determined } \\
\text { aetiology }\end{array}$ & $\begin{array}{l}\text { Undetermined } \\
\text { aetiology }\end{array}$ & \\
\hline 2009 & $159(18.2 \%)$ & $88(19.3 \%)$ & $13(6.1 \%)$ & $2(5.9 \%)$ & $134(19.2 \%)$ & $<0.001$ \\
\hline 2010 & $148(16.2 \%)$ & $100(21.6 \%)$ & $15(8.5 \%)$ & $4(11.4 \%)$ & $138(17.0 \%)$ & 0.004 \\
\hline 2011 & $159(16.1 \%)$ & $112(21.9 \%)$ & $16(7.0 \%)$ & $3(12.5 \%)$ & $130(17.0 \%)$ & $<0.001$ \\
\hline 2012 & $145(15.4 \%)$ & $114(20.5 \%)$ & $12(6.4 \%)$ & $7(14.3 \%)$ & $117(15.9 \%)$ & 0.001 \\
\hline 2013 & $131(14.3 \%)$ & $98(18.2 \%)$ & $15(6.8 \%)$ & $3(9.1 \%)$ & $116(16.3 \%)$ & 0.004 \\
\hline 2014 & $148(18.0 \%)$ & $85(18.7 \%)$ & $15(7.1 \%)$ & $7(20.0 \%)$ & $83(12.9 \%)$ & 0.001 \\
\hline 2015 & $119(15.9 \%)$ & $83(18.8 \%)$ & $18(9.4 \%)$ & $9(21.4 \%)$ & 89 (15.4\%) & 0.043 \\
\hline$P^{b}$ for trend & 0.795 & 0.720 & 0.795 & 0.168 & 0.031 & - \\
\hline Total & $1009(16.2 \%)$ & $680(19.9 \%)$ & $104(7.3 \%)$ & $35(13.9 \%)$ & $807(16.3 \%)$ & $<0.001$ \\
\hline
\end{tabular}

- Chi ${ }^{2}$ test with Holm-Bonferroni correction

b - Cochran-Armitage test for trend with Holm-Bonferroni correction

Table 16. In-hospital mortality in patients treated with rt-PA $(n, \%)$ in association with the aetiology of first-ever ischaemic stroke $(163 ; n=49,452)$ in the Silesian Province between 2009 and 2015

\begin{tabular}{lcccccc}
\multicolumn{1}{r}{ Year } & \multicolumn{3}{c}{ Aetiology of ischaemic stroke } & & Pa \\
Large-artery & Cardio-embolism & $\begin{array}{c}\text { Small-vessel } \\
\text { occlusion (lacune) }\end{array}$ & $\begin{array}{c}\text { Other determined } \\
\text { aetiology }\end{array}$ & $\begin{array}{c}\text { Undetermined } \\
\text { aetiology }\end{array}$ \\
\hline 2009 & $11(36.7 \%)$ & $2(11.1 \%)$ & $0(0 \%)$ & $0(0 \%)$ & $8(22.2 \%)$ & 0.657 \\
2010 & $8(11.6 \%)$ & $5(15.2 \%)$ & $0(0 \%)$ & $0(0 \%)$ & $10(20.4 \%)$ & 1.000 \\
2011 & $12(15.6 \%)$ & $11(17.5 \%)$ & $1(4.8 \%)$ & $0(0 \%)$ & $9(11.4 \%)$ & 1.000 \\
2012 & $18(16.5 \%)$ & $18(16.2 \%)$ & $2(7.7 \%)$ & $0(0 \%)$ & $15(13.3 \%)$ & 1.000 \\
2013 & $15(11.1 \%)$ & $18(13.5 \%)$ & $2(7.1 \%)$ & $0(0 \%)$ & $21(15.1 \%)$ & 1.000 \\
2014 & $32(15.3 \%)$ & $41(23.6 \%)$ & $6(12.5 \%)$ & $1(14.3 \%)$ & $24(13.2 \%)$ & 0.545 \\
2015 & $32(13.5 \%)$ & $26(14.1 \%)$ & $4(8.3 \%)$ & $2(28.6 \%)$ & $42(20.9 \%)$ & 0.545 \\
$P^{b}$ for trend & 0.505 & 1.000 & 0.681 & 0.290 & 1.000 & - \\
Total & $128(14.8 \%)$ & $121(16.9 \%)$ & $15(8.2 \%)$ & $3(9.7 \%)$ & $129(16.2 \%)$ & 0.040
\end{tabular}

- Chi' test with Holm-Bonferroni correction

b- Cochran-Armitage test for trend with Holm-Bonferroni correction 
Table 17. In-hospital mortality in patients treated with rt-PA (n, \%) in association with the aetiology of RIS in the Silesian Province between 2009 and 2015

\begin{tabular}{|c|c|c|c|c|c|c|}
\hline \multirow[t]{2}{*}{ Year } & \multicolumn{5}{|c|}{ Aetiology of ischaemic stroke } & \multirow[t]{2}{*}{$\mathbf{P}^{\mathrm{a}}$} \\
\hline & $\begin{array}{l}\text { Large-artery } \\
\text { atherosclerosis }\end{array}$ & Cardio-embolism & $\begin{array}{c}\text { Small-vessel } \\
\text { occlusion (lacune) }\end{array}$ & $\begin{array}{c}\text { Other determined } \\
\text { aetiology }\end{array}$ & $\begin{array}{l}\text { Undetermined } \\
\text { aetiology }\end{array}$ & \\
\hline 2009 & $1(14.3 \%)$ & $1(50 \%)$ & $0(0 \%)$ & $0(0 \%)$ & $1(14.3 \%)$ & 1.000 \\
\hline 2010 & $3(25 \%)$ & $0(0 \%)$ & $0(0 \%)$ & $0(0 \%)$ & $1(11.1 \%)$ & 1.000 \\
\hline 2011 & $3(15.8 \%)$ & $2(12.5 \%)$ & $0(0 \%)$ & $0(0 \%)$ & $2(22.2 \%)$ & 1.000 \\
\hline 2012 & $6(19.4 \%)$ & $3(17.7 \%)$ & $0(0 \%)$ & $0(0 \%)$ & $4(13.3 \%)$ & 1.000 \\
\hline 2013 & $5(13.5 \%)$ & $5(25 \%)$ & $0(0 \%)$ & $0(0 \%)$ & $2(8 \%)$ & 1.000 \\
\hline 2014 & $10(18.9 \%)$ & $8(19.5 \%)$ & $0(0 \%)$ & $1(50 \%)$ & $2(7.1 \%)$ & 1.000 \\
\hline 2015 & $9(17.7 \%)$ & $4(13.8 \%)$ & $4(28.6 \%)$ & $0(0 \%)$ & $10(26.3 \%)$ & 1.000 \\
\hline$P^{b}$ for trend & 1.000 & 1.000 & 0.419 & 1.000 & 1.000 & - \\
\hline Total & 37 (17.6\%) & $23(17.7 \%)$ & $4(13.3 \%)$ & $1(11.1 \%)$ & $22(15.1 \%)$ & 0.918 \\
\hline
\end{tabular}

- Chi' test with Holm-Bonferroni correction

- Cochran-Armitage test for trend with Holm-Bonferroni correction

Table 18. Secondary stroke prevention in patients with ischaemic stroke (163) in the Silesian Province between 2009 and 2015. Data presented as N (\%)

\begin{tabular}{|c|c|c|c|c|c|}
\hline Year & & Oral antiplatelet drugs & Oral anticoagulant drugs & Antihypertensive drugs & $\begin{array}{l}\text { Direction for vascular } \\
\text { intervention due to arte- } \\
\text { ry stenosis }{ }^{\mathbf{b}}\end{array}$ \\
\hline \multirow[t]{3}{*}{2009} & All & 7,303 (78.7\%) & $2,194(23.7 \%)$ & 7,095 (76.5\%) & $202(2.2 \%)$ \\
\hline & FIS & $5,267(80.0 \%)$ & $1,511(22.9 \%)$ & 4,924 (74.8\%) & $162(2.5 \%)$ \\
\hline & RIS & $1,760(77.3 \%)$ & $605(26.6 \%)$ & $1,869(82.1 \%)$ & $38(1.7 \%)$ \\
\hline \multirow[t]{3}{*}{2010} & All & 8,383 (83.3\%) & $2,650(26.3 \%)$ & 7,939 (78.9\%) & $350(3.5 \%)$ \\
\hline & FIS & $6,177(84.6 \%)$ & $1,879(25.7 \%)$ & 5,678 (77.8\%) & 272 (3.7\%) \\
\hline & RIS & $1,939(80.9 \%)$ & $722(30.1 \%)$ & 1,994 (83.2\%) & $71(3.0 \%)$ \\
\hline \multirow[t]{3}{*}{2011} & All & 8,535 (83.5\%) & $2,608(25.5 \%)$ & $8,233(80.5 \%)$ & 315 (3.1\%) \\
\hline & FIS & $6,191(84.6 \%)$ & $1,846(25.2 \%)$ & $5,862(80.1 \%)$ & $230(3.1 \%)$ \\
\hline & RIS & $2,054(81.6 \%)$ & $694(27.6 \%)$ & $2,086(82.9 \%)$ & $80(3.2 \%)$ \\
\hline \multirow[t]{3}{*}{2012} & All & $8,655(85.0 \%)$ & $2,593(25.5 \%)$ & $8,193(80.4 \%)$ & $379(3.7 \%)$ \\
\hline & FIS & $6,272(85.5 \%)$ & $1,805(24.6 \%)$ & $5,816(79.2 \%)$ & $278(3.8 \%)$ \\
\hline & RIS & $2,087(84.5 \%)$ & $719(29.1 \%)$ & $2,079(84.2 \%)$ & $95(3.8 \%)$ \\
\hline \multirow[t]{3}{*}{2013} & All & $8,682(84.4 \%)$ & $2,301(22.4 \%)$ & $8,331(81.0 \%)$ & $344(3.3 \%)$ \\
\hline & FIS & 6,245 (84.9\%) & $1,588(21.6 \%)$ & $5,912(80.4 \%)$ & $264(3.6 \%)$ \\
\hline & RIS & $2,020(83.4 \%)$ & $579(23.9 \%)$ & $2,031(83.9 \%)$ & $68(2.8 \%)$ \\
\hline \multirow[t]{3}{*}{2014} & All & $8,248(83.7 \%)$ & 1,965 (19.9\%) & $8,187(83.1 \%)$ & $344(3.5 \%)$ \\
\hline & FIS & 5,909 (85.2\%) & $1,380(19.9 \%)$ & $5,820(83.9 \%)$ & $249(3.6 \%)$ \\
\hline & RIS & 1,794 (82.7\%) & 480 (22.1\%) & $1,890(87.1 \%)$ & $86(4.0 \%)$ \\
\hline \multirow[t]{3}{*}{2015} & All & 7,830 (82.2\%) & $1,888(19.8 \%)$ & 7,993 (84.0\%) & $326(3.4 \%)$ \\
\hline & FIS & 5,605 (84.9\%) & 1,335 (20.2\%) & $5,483(83.1 \%)$ & 241 (3.7\%) \\
\hline & RIS & $1,631(81.3 \%)$ & 459 (22.9\%) & $1,773(88.4 \%)$ & $72(3.6 \%)$ \\
\hline \multirow[t]{3}{*}{$P^{a}$ for trend } & All & $<0.001$ & $<0.001$ & $<0.001$ & $<0.001$ \\
\hline & FIS & $<0.001$ & $<0.001$ & $<0.001$ & 0.002 \\
\hline & RIS & $<0.001$ & $<0.001$ & $<0.001$ & $<0.001$ \\
\hline \multirow[t]{3}{*}{ ALL } & All & $57,636(83.0 \%)$ & $16,199(23.3 \%)$ & $55,971(80.6 \%)$ & 2,260 (3.2\%) \\
\hline & FIS & 41,666 (84.3\%) & $11,344(23.0 \%)$ & 39,495 (79.9\%) & $1,696(3.4 \%)$ \\
\hline & RIS & 13,285 (81.7\%) & 4,258 (26.2\%) & 13,722 (84.4\%) & 510 (3.1\%) \\
\hline
\end{tabular}

- Trend test Cochran-Armitage with Holm-Bonferroni correction

b- endarterectomy or angioplasty of cervical artery 
Table 19. Secondary stroke prevention in patients with ischaemic stroke (163) with cardioembolic aetiology in the Silesian Province between 2009 and 2015. Data presented as N (\%)

\begin{tabular}{|c|c|c|c|}
\hline Year & & $\begin{array}{l}\text { Oral antiplatelet } \\
\text { drugs }\end{array}$ & $\begin{array}{c}\text { Oral anticoagulant } \\
\text { drugs }\end{array}$ \\
\hline \multirow[t]{3}{*}{2009} & All & 1,081 (68.9\%) & $589(37.6 \%)$ \\
\hline & FIS & 734 (71.5\%) & $385(37.5 \%)$ \\
\hline & RIS & 296 (65.1\%) & $183(40.2 \%)$ \\
\hline \multirow[t]{3}{*}{2010} & All & 1,203 (74.2\%) & $604(37.2 \%)$ \\
\hline & FIS & $819(74.9 \%)$ & $415(38.0 \%)$ \\
\hline & RIS & $340(73.4 \%)$ & $180(38.9 \%)$ \\
\hline \multirow[t]{3}{*}{2011} & All & 1,402 (72.5\%) & 697 (36.1\%) \\
\hline & FIS & $982(72.8 \%)$ & $503(37.3 \%)$ \\
\hline & RIS & $373(72.9 \%)$ & $180(35.2 \%)$ \\
\hline \multirow[t]{3}{*}{2012} & All & 1,545 (73.9\%) & 766 (36.7\%) \\
\hline & FIS & 1091 (74.1\%) & $519(35.2 \%)$ \\
\hline & RIS & 404 (72.8\%) & 234 (42.2\%) \\
\hline \multirow[t]{3}{*}{2013} & All & 1,445 (71.4\%) & 739 (36.5\%) \\
\hline & FIS & 989 (70.9\%) & 488 (35.0\%) \\
\hline & RIS & $389(72.2 \%)$ & 211 (39.1\%) \\
\hline \multirow[t]{3}{*}{2014} & All & $1,240(65.7 \%)$ & $774(41.0 \%)$ \\
\hline & FIS & 875 (66.7\%) & $536(40.9 \%)$ \\
\hline & RIS & $284(62.6 \%)$ & 207 (45.6\%) \\
\hline \multirow[t]{3}{*}{2015} & All & $1,155(62.5 \%)$ & 734 (39.7\%) \\
\hline & FIS & $821(64.3 \%)$ & 497 (38.9\%) \\
\hline & RIS & 271 (61.3\%) & 195 (44.1\%) \\
\hline \multirow[t]{3}{*}{$P^{a}$ for trend } & All & $<0.001$ & $<0.001$ \\
\hline & FIS & $<0.001$ & 0.253 \\
\hline & RIS & 0.004 & 0.033 \\
\hline \multirow[t]{3}{*}{ ALL } & All & 9,071 (69.9\%) & 4,903 (37.8\%) \\
\hline & FIS & $6,311(70.7 \%)$ & $3,343(37.5 \%)$ \\
\hline & RIS & 2357 (68.9\%) & $1,390(40.6 \%)$ \\
\hline
\end{tabular}

- Trend test Cochran-Armitage with Holm-Bonferroni correction

Lekoubou et al. observed that stroke survivors had a $43 \%$ higher risk of dying after a RS compared to those with FS, because of unfavourable stroke risk profile [30]. In our study, the in-hospital mortality rate was also significantly higher for RS than for FS $(18.4 \%$ vs $17.2 \%$; $<<0.001)$. The same finding concerned RIS vs FIS (16.2\% vs 13.9\%; $\mathrm{p}<0.001)$, and RHS vs FHS $(39.8 \%$ vs $36 \% ; \mathrm{p}=0.004)$. This might be also associated with older age and more expressed clinical symptoms in patients with RS.

We found that the rtPA therapy was applied to a smaller percentage of RIS patients (in $2009-0.7 \%$; in $2015-6.7 \%$ ) than FIS patients (in $2009-1.3 \%$; in $2015-10.3 \%$ ).

In some Western European countries, the percentage of patients with IS treated with rtPA was higher than in the Silesian Province e.g. up to $35 \%$ in the German state of Hesse (2007-2008) [31-33]. Silesia has a dense urban infrastructure and the densest hospital network in Poland, so transportation seems not to be a problem. In our opinion, the main reason for the low percentage of patients treated with rtPA in the Silesian Province remains insufficient knowledge and social awareness of stroke symptoms and the possibilities of treatment [34, 35]. Educational programmes should be regularly conducted among people using all forms of modern media.

\section{Conclusions}

1. Recurrent strokes constituted about one fifth of all stroke hospitalisations. However, the recurrence rate of ischaemic stroke has systematically decreased over the last decade. This is evidence of better secondary stroke prevention.

2. Large-artery atherosclerosis and cardioembolisms were significantly more often recognised in RIS than in FIS, but the main reason for RIS was large artery atherosclerosis.

3. The in-hospital mortality rate was significantly higher for RS than for FS.

4. Patients with RIS were almost two times less often treated with rtPA than patients with FIS.

5. This was the first such comprehensive analysis of RS in the Silesian Province, Poland. This study could help in the implementation of appropriate educational programmes, and thus help to improve the health status of society.

\section{Limitations of the study}

There were a few limitations to this research, as described in previous studies $[15,16]$. Firstly, in our paper we analysed only stroke-related hospitalisations, but in Poland almost all patients with AS are admitted to hospital. Secondly, it is possible that in the case of some ASs the questionnaires might not have been sent to the NHF. Thirdly, we could not estimate the number of stroke-related deaths that had occurred prior to the patient's arrival at hospital, and therefore the true hospitalised incidence of stroke might be underestimated. Fourthly, we only analysed the questionnaire data and the information those questionnaires contained. As a result, human error could have occurred. Fifthly, the data was anonymous so we could not analyse the trends for strokes.

\section{Acknowledgments}

The authors wish to thank Professor Krystyna Pierzchala, $\mathrm{MD}, \mathrm{PhD}$, the former Consultant in Neurology for the Silesian Province, for supporting the initiative of the epidemiological study on stroke in the Silesian Province.

Funding: None declared.

Conflict of interest: None declared.

\section{References}

1. Thorvaldsen P, Asplund K, Kuulasmaa K, et al. Stroke incidence, case fatality, and mortality in the WHO MONICA project. World Health 
Organization Monitoring Trends and Determinants in Cardiovascular Disease. Stroke. 1995; 26(3): 361-367, indexed in Pubmed: 7886707.

2. Ryglewicz D, Ryglewicz D. [Epidemiology of stroke: a prospective community-based study of stroke in Warsaw, 1991-1992]. Neurol Neurochir Pol. 1994; 28(1 Suppl 1): 35-49, indexed in Pubmed: 8065543.

3. Czlonkowska A, Ryglewicz D, Weissbein T, et al. A prospective community-based study of stroke in Warsaw, Poland. Stroke. 1994; 25(3): 547-551, indexed in Pubmed: 8128505.

4. Słowik A, Turaj W, Zwolińska G, et al. Stroke attack rates and case fatality in the Krakow Stroke Registry. Neurol Neurochir Pol. 2007; 41(4): 291-295, indexed in Pubmed: 17874336.

5. Niewada M, Skowrońska M, Ryglewicz D, et al. Polish National Stroke Prevention and Treatment Collaborative Group, Polish National Stroke Prevention and Treatment Collaborative Group. Acute ischemic stroke care and outcome in centers participating in the Polish National Stroke Prevention and Treatment Registry. Stroke. 2006; 37(7): 1837-1843, doi: 10.1161/01.STR.0000226992.39847. ef, indexed in Pubmed: 16741176.

6. Członkowska A, Niewada M, Sarzyñska-Długosz I, et al. Ten years of stroke programmes in Poland: where did we start? Where did we get to? Int J Stroke. 2010; 5(5): 414-416, doi: 10.1111/j.1747-4949.2010.00470.x, indexed in Pubmed: 20854627.

7. Wawrzyńczyk M, Pierzchała K, Braczkowska B, et al. Estimates of stroke incidence and case fatality in Zabrze, 2005-2006. Neurol Neurochir Pol. 2011; 45(1): 3-10, indexed in Pubmed: 21384287.

8. Kozera G, Chwojnicki K, Sobolewski P, et al. Epidemiology and treatment of stroke in the Pomeranian Province and the Swietokrzyskie-Sandomierz Region in the light of data from the Pomeranian Stroke Registry. In Polish]. Udar Mozgu. 2010; 12: 1-9.

9. Jucha R, Jucha R. Incidence and mortality due to stroke in the population of Krosno and Krosno County. In Polish]. Przeg Lek. 2013; 70: 191-4.

10. Sienkiewicz-Jarosz H, Głuszkiewicz M, Pniewski J, et al. Incidence and case fatality rates of first-ever stroke - comparison of data from two prospective population-based studies conducted in Warsaw. Neurol Neurochir Pol. 2011; 45(3): 207-212, indexed in Pubmed: 21866477.

11. Bembenek JP, Karliński M, Kobayashi A, et al. The prestroke use of vitamin $\mathrm{K}$ antagonists for atrial fibrillation - trends over 15 years. Int J Clin Pract. 2015; 69(2): 180-185, doi: 10.1111/ijcp.12486, indexed in Pubmed: 25358816.

12. Bembenek JP, Karlinski M, Mendel TA, et al. Temporal trends in vascular risk factors and etiology of urban Polish stroke patients from 1995 to 2013. J Neurol Sci. 2015; 357(1-2): 126-130, doi: 10.1016/j. jns.2015.07.011, indexed in Pubmed: 26187297.

13. Bembenek JP, Karlinski M, Kurkowska-Jastrzebska I, et al. Changes in pre-hospital management of vascular risk factors among patients admitted due to recurrent stroke in Poland from 1995 to 2013. Arch Med Sci. 2016; 12(4): 754-759, doi: 10.5114/aoms.2016.60963, indexed in Pubmed: 27482236.

14. Gierlotka M, Labuz-Roszak B, Wojtyniak B, et al. Early and One-Year Outcomes of Acute Stroke in the Industrial Region of Poland During the Decade 2006-2015: The Silesian Stroke Registry. Neuroepidemiology. 2018; 50(3-4): 183-194, doi: 10.1159/000487324, indexed in Pubmed: 29587253.

15. Starostka-Tatar A, Łabuz-Roszak B, Skrzypek M, et al. Characteristics of hospitalizations due to acute stroke in the Silesian Province, Poland, between 2009 and 2015. Neurol Neurochir Pol. 2018; 52(2): 252-262, doi: 10.1016/j.pjnns.2017.11.010, indexed in Pubmed: 29221869.
16. Łabuz-Roszak B, Starostka-Tatar A, Lasek-Bal A, et al. Diagnostics, treatment and secondary prevention of ischemic stroke in the Silesian Province, Poland between 2009 and 2015. Neurol Neurochir Pol. 2018; 52(2): 235-242, doi: 10.1016/j.pjnns.2017.11.003, indexed in Pubmed: 29198761.

17. Chwojnicki K, Ryglewicz D, Wojtyniak B, et al. Acute Ischemic Stroke Hospital Admissions, Treatment, and Outcomes in Poland in 2009-2013. Front Neurol. 2018; 9: 134, doi: 10.3389/fneur.2018.00134, indexed in Pubmed: 29593634.

18. Feigin VL, Lawes CMM, Bennett DA, et al. Worldwide stroke incidence and early case fatality reported in 56 population-based studies: a systematic review. Lancet Neurol. 2009; 8(4): 355-369, doi: 10.1016/ S1474-4422(09)70025-0, indexed in Pubmed: 19233729.

19. Sedova P, Brown RD, Zvolsky M, et al. Incidence of Hospitalized Stroke in the Czech Republic: The National Registry of Hospitalized Patients. J Stroke Cerebrovasc Dis. 2017; 26(5): 979-986, doi: 10.1016/j.jstrokecerebrovasdis.2016.11.006, indexed in Pubmed: 27955808.

20. Béjot Y, Daubail B, Giroud M, et al. Epidemiology of stroke and transient ischemic attacks: Current knowledge and perspectives. Rev Neurol (Paris). 2016; 172(1): 59-68, doi: 10.1016/j.neurol.2015.07.013, indexed in Pubmed: 26718592.

21. Mohan KM, Crichton SL, Grieve AP, et al. Frequency and predictors for the risk of stroke recurrence up to 10 years after stroke: the South London Stroke Register. J Neurol Neurosurg Psychiatry. 2009; 80(9): 1012-1018, doi: 10.1136/jnnp.2008.170456, indexed in Pubmed: 19465412.

22. Petty GW, Brown RD, Whisnant JP, et al. Survival and recurrence after first cerebral infarction: a population-based study in Rochester, Minnesota, 1975 through 1989. Neurology. 1998; 50(1): 208-216, doi: 10.1212/wnl.50.1.208, indexed in Pubmed: 9443482.

23. Hardie K, Jamrozik K, Hankey GJ, et al. Trends in five-year survival and risk of recurrent stroke after first-ever stroke in the Perth Community Stroke Study. Cerebrovasc Dis. 2005; 19(3): 179-185, doi: 10.1159/000083253, indexed in Pubmed: 15644631.

24. Hartmann A, Rundek T, Mast $\mathrm{H}$, et al. Mortality and causes of death after first ischemic stroke: the Northern Manhattan Stroke Study. Neurology. 2001; 57(11): 2000-2005, doi: 10.1212/wnl.57.11.2000, indexed in Pubmed: 11739816.

25. Lainay C, Benzenine E, Durier J, et al. Hospitalization within the first year after stroke: the Dijon stroke registry. Stroke. 2015; 46(1): 190 196, doi: 10.1161/STROKEAHA.114.007429, indexed in Pubmed: 25378425.

26. Raffe F, Jacquin A, Milleret 0 , et al. Evaluation of the possible impact of a care network for stroke and transient ischemic attack on rates of recurrence. Eur Neurol. 2011; 65(4): 239-244, doi: 10.1159/000326298, indexed in Pubmed: 21474937.

27. Lovett JK, Coull AJ, Rothwell PM, et al. Early risk of recurrence by subtype of ischemic stroke in population-based incidence studies. Neurology. 2004; 62(4): 569-573, doi: 10.1212/01. wnl.0000110311.09970.83, indexed in Pubmed: 14981172.

28. Chang T, Gajasinghe S, Arambepola C, et al. Prevalence of Stroke and Its Risk Factors in Urban Sri Lanka: Population-Based Study. Stroke. 2015; 46(10): 2965-2968, doi: 10.1161/STROKEAHA.115.010203, indexed in Pubmed: 26330444.

29. de Carvalho JJ, Alves MB, Viana GÁ, et al. Stroke epidemiology, patterns of management, and outcomes in Fortaleza, Brazil: a hospital-based multicenter prospective study. Stroke. 2011; 42(12): 3341-3346, doi: 10.1161/STROKEAHA.111.626523, indexed in Pubmed: 22052521. 
30. Lekoubou A, Nkoke C, Dzudie A, et al. Recurrent Stroke and Early Mortality in an Urban Medical Unit in Cameroon. J Stroke Cerebrovasc Dis. 2017; 26(8): 1689-1694, doi: 10.1016/j. jstrokecerebrovasdis.2017.03.031, indexed in Pubmed: 28416089.

31. Addo J, Bhalla A, Crichton S, et al. Provision of acute stroke care and associated factors in a multiethnic population: prospective study with the South London Stroke Register. BMJ. 2011; 342: d744, doi: 10.1136/bmj.d744, indexed in Pubmed: 21349892.

32. Stolz E, Hamann GF, Kaps M, et al. Regional differences in acute stroke admission and thrombolysis rates in the German federal state of Hesse. Dtsch Arztebl Int. 2011; 108(36): 607-611, doi: 10.3238/ arztebl.2011.0607, indexed in Pubmed: 21966319.

33. ISD Scotland. (2014). Scottish Stroke Care Audit, 2014 National Report. Available:. http:// www.strokeaudit.scot.nhs.uk/Downloads/2014_report/SSCA-report-2014-web.pdf..

34. Łabuz-Roszak B, Pierzchała K, Porosińska A, et al. at al. Ocena wiedzy społeczeństwa polskiego na temat udaru mózgu. Ann Acad Med Siles. 2006; 60(3): 196-201.

35. Łabuz-Roszak B, Otocka D, Bryk R, et al. [Knowledge on cardiovascular risk factors and symptoms of stroke among inhabitants of rural communite]. Wiad Lek. 2018; 71(7): 1214-1221, indexed in Pubmed: 30448787. 